\title{
DA INSERÇÃO AO EMPODERAMENTO: ANÁLISE DA TRAJETÓRIA DE DIRETORAS DE INSTITUIÇÕES PRIVADAS DE ENSINO SUPERIOR DE BELO HORIZONTE ${ }^{1}$
}

\author{
Míriam Rabelo Gontijo ${ }^{2}$ \\ Marlene Catarina de Oliveira Lopes Melo ${ }^{3}$
}

http://dx.doi.org/10.1590/1413-2311.157.59314

\begin{abstract}
RESUMO
Este estudo analisa as relações de gênero no setor educacional, por meio de pesquisa bibliográfica e análise de relatos de histórias de vida de diretoras de Instituições de Ensino Superior privadas. A participação das mulheres no mercado de trabalho vem se consolidando com o passar dos anos, com destaque para a área da educação, fazendo com que esse processo de inserção do gênero feminino seja constante e gradativo. No entanto, ao assumir cargos na escala hierárquica, principalmente nas instituições de ensino superior, percebe-se que, pouco a pouco, seus lugares passam a ser ocupados por homens que, em grande parte das situações, estão no comando e são os responsáveis pelas principais tomadas de decisões que dizem respeito ao futuro das instituições. Neste estudo, três diretoras de instituições de ensino superior privadas pertencentes a grupos educacionais localizados em Belo Horizonte, Minas Gerais, foram convidadas a compartilhar um pouco de sua trajetória rumo ao empoderamento. Constatou-se, ao final do estudo, que, embora as três diretoras estejam adiantadas em seu processo de empoderamento, situações cotidianas mostram a existência de um "teto de vidro" construído por meio de um preconceito velado no ramo educacional.
\end{abstract}

Palavras-chave: Mercado Educacional. Mulher. Teto de vidro. Empoderamento.

\section{FROM INCLUSION TO EMPOWERMENT: ANALYSIS OF THE TRAJECTORY OF DIRECTORS OF PRIVATE HIGHER EDUCATION INSTITUTIONS OF BELO HORIZONTE}

\begin{abstract}
This study investigated gender relations in the higher education sector, by means of the analysis of directors' life-histories from private higher education institutions. The participation of women in the labor market has been consolidated overs the years, especially in the education sector, making the woman insertion process constant and gradual. Notwithstanding, in considering high hierarchy positions, especially in higher education

\footnotetext{
${ }^{1}$ Recebido em 13/10/2015; aprovado em 26/05/2017.

${ }^{2}$ Faculdade Novos Horizontes - miriamrgontijo@ hotmail.com.

${ }^{3}$ Faculdade Novos Horizontes - sec-diretoria@ unihorizontes.br.

REAd | Porto Alegre - Vol. 23 - No Especial - Dezembro 2017 - p. 126-157
} 
institutions, it is clear that their places are gradually being taken over by men in charge of decision-making concerning the future of the institutions. In the present study, three directors of private higher education institutions located in Belo Horizonte, Minas Gerais, were invited to share their trajectories towards empowerment. It was observed that although the three directors are in the early stage of the empowerment process, everyday situations demonstrate the existence of a "glass ceiling" built on a hidden bias pervading the educational field.

Key-words: Educational market. Woman. Glass ceiling. Empowerment.

\title{
DE LA INSERCIÓN AL EMPODERAMIENTO: UN ANÁLISIS DE LA
}

\section{TRAYECTORIA DE DIRECTORAS DE INSTITUCIONES PRIVADAS DE LA EDUCACIÓN SUPERIOR DE BELO HORIZONTE}

\begin{abstract}
RESUMEN
El presente estudio analizó las relaciones de género en el sector de la educación superior, por medio de investigación bibliográfica y análisis de relatos de historias de vida de directoras de instituciones privadas de educación superior. La participación de las mujeres en el mercado de trabajo viene consolidándose con el paso del tiempo, especialmente en las áreas de la educación, haciendo que ese proceso de inserción del género femenino sea constante y gradual. Sin embargo, al considerar puestos en la alta jerarquía, principalmente en las instituciones de educación superior, se nota que, poco a poco, sus lugares son ocupados por hombres que, a menudo, están al mando y son los responsables de las principales tomas de decisiones que se refieren al futuro de las instituciones. En este estudio, tres directoras de instituciones de educación superior privadas pertenecientes a grupos educacionales ubicados en Belo Horizonte, Minas Gerais, fueron invitadas a compartir una parte de sus trayectorias hacia el empoderamiento. Se observó que, a pesar del adelanto de los procesos de empoderamiento de las tres directoras, situaciones cotidianas demuestran la existencia de un "techo de cristal" construido por medio de un prejuicio disimulado en el sector educacional.
\end{abstract}

Palabras-clave: Mercado Educacional. Mujer. Techo de cristal. Empoderamiento.

\section{INTRODUÇÃO}

O perceptível aumento de mulheres em cargos de chefia e diretoria, que antes tendiam a ser ocupados exclusivamente por homens, vem ganhando espaço nas discussões acadêmicas devido ao impacto causado no âmbito social (MELO, 2009). Pouco a pouco, a mulher tem assumido um papel diferente do de outros tempos, conseguindo, além da inserção no mercado de trabalho, ser considerada, finalmente, profissional de grande competência nas mais diversas áreas; aos poucos ela vem reparando brechas deixadas pelo tempo em que foi silenciada, dominada e tida como invisível (PERROT, 2007) pela sociedade. No entanto, também é verdade o fato de que, em geral, as mulheres, têm uma ascensão profissional mais REAd | Porto Alegre - Vol. 23 - No Especial - Dezembro 2017 - p. 126-157 
lenta- mesmo assim, para que isso aconteça, elas têm que mostrar melhor performance do que a dos homens (BILLING; ALVESSON, 1994).

Ainda assim, pesquisas mostram que a mulher tem avançado e garantido maior participação no mercado de trabalho brasileiro (IBGE, 2012). No entanto, elas nem sempre revelam a qualidade desse trabalho; ou seja, não fica claro se há condições laborais favoráreis ou se tratam-se de subempregos destinados à mulher por consequência de suas desvantagens históricas no mercado de trabalho. Com relação à sua educação, tem-se que apenas entre 1758 e 1870 a mulher pôde ingressar em uma escola formal, e, com isso, passou a contar com oportunidades de trabalho fora do lar, recebendo, a princípio, o cargo de professora, pelo motivo de os homens não poderem lecionar para mulheres naquele tempo. As mulheres garantiriam sua presença no mercado de trabalho a partir de então (STAMATTO, 2002). Sobre isso, a autora ainda aponta que apenas entre 1842 a 1847 surgiu o que pode ser considerada a primeira escola de formação para o magistério feminino do país, já que eram escolas normais com um curso especial para mulheres. Além dessa herança histórica, Louro (2010) defende a crescente força da psicologia na elaboração de teorias pedagógicas que enfatizam a função apoiadora do exercício do magistério. A autora explana que a representação masculina enquanto professor está ligada à autoridade e ao conhecimento, enquanto a posição feminina na docência está ligada ao cuidado e ao apoio "maternal".

Enquanto as mulheres são colocadas em posições que privilegiam o cuidado com o outro, muitas vezes por questões simbólicas, há um fenômeno referente à tendência em haver maior quantidade de homens nas posições hierarquicamente mais altas nas organizações. Esse fenômeno foi estudado por Steil (1997), Hultin (2003), entre outros, pela ótica do "teto de vidro", que pode ser explicado, em poucas palavras, como um preconceito velado que impede o avanço da mulher para posições de maior hierarquia. Não há nada aparente que as impeça de avançar, mas tal progresso se torna improvável e impraticável, na visão dos autores. O teto de vidro simboliza, portanto, a complexidade dos desafios enfrentados pela mulher requerendo persistência, conscientização da sua competência, bem como dos desafios im(previsíveis) para transpô-los.

Para este estudo, foi proposta uma análise da trajetória de diretoras e reitoras de instituições de ensino superior privada da cidade de Belo Horizonte, Minas Gerais. A escolha de Belo Horizonte para o desenvolvimento desta pesquisa justifica-se pelo crescimento da presença de grandes grupos empresariais da educação na região e pela acessibilidade na coleta de dados. Os objetivos específicos deste estudo foram: a) conhecer a visão das diretoras sobre 
o seu próprio empoderamento; b) identificar indícios de dominação masculina no meio educacional por meio de relatos sobre dificuldades e preconceitos enfrentados pelas diretoras em sua trajetória profissional; c) mostrar as perspectivas das diretoras quanto à sua ascensão profissional; e d) conhecer as habilidades e atitudes adquiridas por elas, bem como as estratégias utilizadas para a permanência no cargo.

O artigo está estruturado da seguinte forma: introdução, referencial teórico, contextualização da pesquisa, metodologia, relatos de histórias de vida, análise dos dados da pesquisa, considerações finais e referências.

\section{REFERENCIAL TEÓRICO}

\subsection{TRAJETÓRIA DA INSERÇÃO DA MULHER NO MERCADO DE TRABALHO EDUCACIONAL}

A escola formal, no Brasil, destinou-se por muitos anos à elite branca e masculina (LOURO, 1997) sendo, por muito tempo, a única forma de educação para os adultos. Às mulheres a educação formal por muito tempo foi negada, fazendo com que elas participassem, quando muito, das aulas da catequese. Elas se dedicavam exclusivamente, portanto, ao trabalho doméstico, a orações, cantos e aos cuidados com a família (CUNHA, 1999).

Nesse contexto de desigualdade educacional, a solução para as mulheres que queriam crescer intelectualmente eram as aulas em casa ou em algumas instituições como os conventos, que prezavam pela castidade das mulheres que ali frequentavam. Percebe-se, dessa forma, que o objetivo não era preparar a mulher para a vida pública, mas para a vida religiosa ou para serem boas mães e esposas (RIBEIRO, 2000). Tais ensinamentos vinham cobertos de conceitos patriarcais que aniquilavam o desenvolvimento do senso crítico da mulher, impedindo-a de pensar por si mesma e dificultado que se tornasse autora de sua própria história.

Após algumas reformas na educação, a mulher pôde adentrar as salas de aulas como aluna, mas separada dos homens. Além disso, havia discriminação na oferta educacional. As mulheres não tinham direito às mesmas disciplinas que os homens e tinham que aprender na escola os ofícios do lar. Assim, da mesma forma que não tinham colegas de sala do sexo masculino, também não tinham professores, e sim professoras. Percebe-se, naquele momento, a sutil possibilidade da entrada da mulher no mercado de trabalho.

REAd | Porto Alegre - Vol. 23 - No Especial - Dezembro 2017 - p. 126-157 
Entre 1758 e 1870, a mulher pôde finalmente começar a trabalhar fora. Como não tinham formação específica por não terem contado com escolas que as qualificassem formalmente, recebiam, por consequência, salários menores que os homens. Além disso, deveriam ter atestado de boa conduta e permissão do pai ou marido, se casadas, para exercer a profissão; se viúvas, deveriam apresentar certidão de óbito; caso fossem separadas, deveriam justificar sua separação, juntamente com a comprovação de comportamento honrado (RIBEIRO, 2000).

Os salários baixos outrora praticados ainda são uma realidade para muitas mulheres na contemporaneidade. Melo (2009) destacou, por meio de uma pesquisa entre gerentes, que dentre aqueles que recebem os mais altos salários, há quase três vezes mais homens que mulheres. Os baixos salários podem ser uma herança cultural dos tempos em que as mulheres não eram tão qualificadas por não terem os mesmos acessos à educação quanto os homens, além de trabalharem apenas para complementar a renda familiar. Aquino, Menezes e Marinho (1995) afirmam que o trabalho das mulheres, até pouco tempo, teve um caráter de complementação do sustento da família, por isso sua inserção no mercado de trabalho se deu em atividades de baixa qualificação e com consequente baixa remuneração.

Apenas no século XX passou a haver uma maior participação feminina no mercado de trabalho, advinda de alguns eventos que marcaram esse início. Pode-se citar, por exemplo, a Revolução Russa, ocorrida em 1917, que teve entre suas consequências, a luta por equidade de acesso ao trabalho de homens e mulheres; além da igualdade salarial para ambo os sexos (GOMES, 2005). Outro evento marcante foi a Grande Recessão, que trouxe um aumento significativo da taxa de desemprego. A mulher, por concordar com uma remuneração menor, adentrou o mercado de trabalho para conseguir levar para casa o salário perdido pelo desemprego do marido. Daí em diante, com o aparecimento da máquina de escrever e do telefone, as mulheres passaram a ocupar cargos que não interessavam aos homens que, em sua grande parte, preferiam o trabalho nas fábricas em vez de escritórios. No entanto, o evento que mais marcou a entrada da mulher no mercado de trabalho foi a $2^{\mathrm{a}}$ Guerra Mundial. Com a ausência dos homens, as mulheres tiveram que se mobilizar para que a produção permanecesse. Assim, na segunda metade do século XX, outras oportunidades apareceram gradativamente para a mulher (LEITE, 1994).

Para explicar essas transformações ocorridas no mercado e na família, Castells (1999, p. 208) considera quatro elementos que contribuíram para a redefinição dos arranjos sociais: "o crescimento da economia informacional, as mudanças no processo tecnológico de 
reprodução, os movimentos feministas e a difusão de ideias em massa, com o advento da globalização". A globalização, advinda das novas tecnologias, trouxe consigo a oportunidade de a mulher adentrar o mercado; todavia, pouco se discute acerca da qualidade das condições de trabalho a que ela se submete.

Essas transformações resultaram em uma grande mudança no campo das relações de gênero, mas as tradições, os valores, as crenças e ideias difundidas em 500 anos de história estão enraizadas demais para serem prontamente mudadas. A ideia da subordinação da natureza da mulher às vontades masculinas ainda impera e, embora hoje as mulheres ocupem diversos cargos, incluindo alguns de alta hierarquia, a função tradicional de cuidado e administração do lar continua sob seus cuidados. Isso faz com que suas responsabilidades da casa tenham que ser equilibradas com as responsabilidades profissionais, gerando uma jornada dupla de trabalho (CARREIRA; AJAMIL; MOREIRA, 2001). Corroborando com essa ideia, Gomes (2005, p. 6) aponta que ainda se destacam os salários menores em relação aos dos homens, além da " dupla jornada com o princípio de que a vida doméstica é trabalho feminino, falta de voz nos espaços de decisão, entre outras coisas".

Assim, não há dúvidas de que avanços referentes à inserção da mulher no mercado de trabalho sejam notórios. No entanto, conforme foi possível verificar pelas ideias expostas, muito ainda há para ser feito em prol da valorização da mulher no ambiente laboral para que a ideia da submissão feminina ceda lugar à ideia da mulher atuante e pró-ativa que desponta na atualidade.

\subsection{DA SUBMISSÃO AO EMPODERAMENTO FEMININO}

A submissão feminina iniciou-se juntamente com a história, marcada pela sobreposição do poder masculino em detrimento da vontade feminina. Sobre isso, Beauvoir (1980) escreveu que foi sem perceber, sem refletir, sem observar, sem participar - que as mulheres se tornaram o segundo sexo. Pode-se, também, dizer que a submissão está ligada ao poder sobre os corpos, na ótica de Foucault (1995). O autor destaca que o poder tem uma relação direta com o corpo humano, que pode ser interpretado como a articulação de fatores como alimentação, sexualidade ou, ainda, dos próprios mecanismos do poder em suas diversas faces.

A história das mulheres é repleta de preconceito, imposição e reclusão, determinados pela sociedade patriarcal dominadora. Durante a história, a própria mulher compactuou com

REAd | Porto Alegre - Vol. 23 - No Especial - Dezembro 2017 - p. 126-157 
essa realidade:

A própria mulher reconhece que o universo em seu conjunto é masculino; os homens modelaram-no, dirigiram-no e ainda hoje o dominam; ela não se considera responsável; [...] nunca emergiu, como um sujeito, em face dos outros membros da coletividade; fechada em sua carne, em sua casa, aprende-se como passiva em face desses deuses de figura humana que definem fins e valores (BEAUVOIR, 1980, p. $364)$.

Bourdieu (2011) acredita em uma força simbólica como sendo a força que age sobre os corpos. Essa força acontece como que por magia, sem coerção física, mas com o apoio de predisposições colocadas como molas propulsoras. Nessa perspectiva, o autor esclarece que o ser humano submisso é destituído do poder de dar sentido. Ele se encontra em tamanha incerteza sobre seu próprio ser social e sua identidade que perde o poder de dar sentido à sua vida e não consegue direcionar sua existência, sendo condenado a viver de forma alienada, orientado apenas pelos outros e não por si mesmo. Assim, o destino dos dominados é a eterna espera que tudo venha daqueles que detêm o poder sobre o jogo. O ser dominado vive, nas palavras do autor, a esperança objetiva e subjetiva de ganhos que pode proporcionar; logo, mestres em jogar com a angústia que nasce inevitavelmente da tensão entre a intensidade da espera e a improbabilidade da satisfação.

Segundo Bourdieu (2010), o início da inferiorização da mulher, bem como sua exclusão, está no sistema mítico-ritual que faz da relação homem/mulher o princípio da divisão de todo o universo, em que o mercado matrimonial é a base de troca. Nesse sentido, as mulheres só podem ser vistas como objetos de troca, cuja função nada mais é que contribuir para a perpetuação do capital simbólico em poder dos homens. Sobre a dominação masculina, Bourdieu (2010, p. 49) aponta que:

\footnotetext{
Não se pode, portanto, pensar esta forma de dominação senão ultrapassando a alternativa da pressão (pelas forças) e do consentimento (às razões), da coerção mecânica e da submissão voluntária, livre, deliberada, ou até mesmo calculada. $\mathrm{O}$ efeito da dominação simbólica [...] se exerce não na lógica pura das consciências cognosecentes, mas através de esquemas de percepção, de avaliação e de ação que são construtivos dos habitus [...].
}

O autor defende que a dominação masculina está tão enraizada no inconsciente das pessoas, que elas não mais a percebem. Ele ainda salienta que sem uma postura crítica, que perceba essa ordem injusta, violenta e dominadora, tal situação jamais poderá ser contida. Dessa forma, apenas ações políticas, que entendam todos os efeitos da dominação no intuito de mudar a consciência de todos, podem servir para uma vivência mais justa em termos de 
relações de gênero (BOURDIEU, 2010).

Concordando com a teoria da dominação masculina sobre a mulher, Ray (2006) afirma que ela vem sendo subjugada e controlada pela sociedade patriarcal. A natureza desse controle e subjugação varia de sociedade para sociedade e não pode ser considerada como uma constante, embora aconteça em âmbito global. As relações de gênero, dinâmicas e complexas, têm mudado no decorrer da história, mesmo que com intensidade diferenciada, sendo o patriarcado um dos elementos estruturantes da dominação masculina. Para Walby (1990), o patriarcado é um sistema social no qual a figura masculina tem a autoridade central na organização social, inclusive no que tange à mulheres, crianças e propriedade. É, portanto, o principal responsável pela submissão das mulheres. Complementando essa ideia, Rawat (2014) considera que as sociedades patriarcais que imperam globalmente são construtos sociais e ideológicos nos quais homens (os patriarcas) são considerados superiores às mulheres.

A palavra "empoderamento" significa autorizar, delegar ou dar poder legal a alguém (RAWAT, 2014). Muitos estudos foram feitos analisando o empoderamento de forma geral e, em particular, o empoderamento da mulher. Em nível macro, as análises centram-se na inclusão social. Para as mulheres, o empoderamento significa o ganho de controle de suas vidas em relação à família, comunidade e sociedade (JEJEEBHOY,2000).

Melo (2012) salienta que o empoderamento não pode ser considerado um processo com um começo bem delineado e um final com as mesmas experiências para todas as mulheres, uma vez que não existem fórmulas ou projetos, receitas ou modelos prescritos que mostrem à mulher como elas devem agir para o seu empoderamento. Ao contrário, ele é moldado para cada indivíduo com base em suas próprias experiências, contextos e histórias. A mulher que passa pelo processo de empoderamento acredita que pode lidar com eventos, situações e/ ou pessoas com as quais ela confronta. Assim, as estratégias que fortalecem o senso de determinação de uma pessoa, fazem com que ela se sinta mais empoderada (RAWAT, 2014).

Melo e Lopes (2011) consideram seis fatores para analisar o processo de empoderamento das mulheres nas organizações: (1) cognitivo-analítico, que está diretamente relacionado ao saber, ao conhecimento e à qualificação; (2) subjetivo, que aponta a experiência subjetiva, que se manifesta por meio da autoconfiança, como essencial ao empoderamento psicológico; (3) político, que retrata a forma como a profissional vivencia as relações de poder no espaço organizacional; (4) econômico, que está associado à mulher 
conseguir sua própria renda para complementar o orçamento familiar, além de conceder-lhe a independência financeira; (5) social, que diz respeito ao reconhecimento da família, do grupo social e pela organização; e (6) cultural, que se refere ao poder conquistado no âmbito organizacional, social e familiar ao entrecruzar de outra forma as relações étnicas, sociais, culturais e históricas.

À luz dessas ideias, conclui-se então que o empoderamento gera bem-estar, enquanto a submissão gera tensão e insatisfação.

\subsection{ORGANIZAÇÕES E A QUESTÃO DO GÊNERO: O FENÔMENO DO “TETO DE VIDRO”}

Para iniciar os estudos acerca do "teto de vidro" nas organizações, alguns dados são relevantes para ressaltar a importância e a seriedade do tema. Em um estudo do Instituto Ethos (2010) nas 500 maiores empresas brasileiras, foi constatado que a desigualdade entre trabalhadores homens e mulheres ainda é grande no país. No quadro funcional há uma diferença menor - a presença feminina representa 33,1\% dos postos de trabalho. No entanto, conforme o nível hierárquico se eleva, há um declínio da participação das mulheres: 26,8\% na supervisão, $22,1 \%$ na gerência e $13,7 \%$ no executivo. Houve então, segundo os dados do estudo, um afunilamento nos níveis de maior hierarquia.

Levando em consideração que, quanto à presença feminina na sociedade brasileira, as mulheres representam $51,3 \%$ do total da população, 43,9\% da população economicamente ativa (PEA) e 42,6\% da ocupada, verifica-se que, "além da desigualdade, há uma subrepresentação das mulheres nas empresas da amostra” (ETHOS, 2010, p. 12).

Pela percepção de constantes inconsistências referentes à mulher e ao mundo laboral ao seu redor, na década de 80, nos Estados Unidos, estudos foram iniciados para perceber qual era a barreira que impedia a mulher de chegar ao seu objetivo profissional, sendo introduzida, então, a denominação "teto de vidro". Esse conceito descreve uma barreira sutil, quase invisível, mas suficientemente forte para impedir as mulheres de ascenderem socialmente. Essa barreira funciona como um impeditivo focado no gênero, e não nas inabilidades ou na falta de competências profissionais, o que afeta as mulheres como um grupo (POWELL; BUTTERFILED, 1994).

Em seus estudos, Durbin (2002) apresenta que o "teto de vidro" manifesta-se em ações negativas contra as mulheres, impedindo-as de se alavancarem profissionalmente. Isso ocorre 
pela estereotipagem que a sociedade apresenta com relação à mulher estar em cargos de comando. Assim, o autor afirma que o "teto de vidro" passa a ser um obstáculo cristalino e tênue entre as mulheres e suas carreiras. Baxter e Wrigth (2000) compartilham dessa ideia e acrescentam que a dificuldade e os obstáculos enfrentados aumentam à medida que o cargo se eleva.

Hultin (2003) explica que o "teto de vidro" permite que as mulheres avancem até um determinado ponto, porém não conseguem ir além. Já os homens progridem mais rapidamente e com menos qualificação que as mulheres. É a chamada escada rolante de vidro, na visão do autor.

A essa conceituação, Melo (2009) acrescenta que o "teto de vidro" tem sua diversidade de formas e intensidades que variam dependendo da organização. Assim, as relações de gênero e de poder precisam ser interpretadas à luz das regras sócio-culturais vigentes nos espaços onde ocorrem as relações de poder vivenciadas pelos agentes sociais.

Nessa perspectiva, Motowidlo (1986) já pontuava uma ideia de preconceito inconsciente que pode resultar de fatores como: receio de selecionar um candidato inaceitável, que não se adapte à função; atração pessoal por um candidato que seja parecido com a própria pessoa que está selecionando; e a ideia pré-programada do estereótipo de um candidato ideal. Esses fatores podem afetar a forma de enxergar o outro, levando o gênero a ser um fator decisivo ao se escolher um candidato para uma posição de liderança dentro da organização. Sobre essa discriminação relacionada ao gênero, Probst (2003) salienta que a presença da mulher no mercado de trabalho vem acompanhada de discriminação quanto à qualidade das ocupações, tanto no setor formal, quanto no informal e no tocante ao salário.

Quanto à presença do fenômeno do "teto de vidro" dentro das instituições de ensino, Souza (2006) esclarece que a presença masculina não se deve à maior qualificação dos homens, mas sim à decorrência do domínio do sexo. "Isso porque o sexo é político, pois as tradicionais formas de se compreender o papel dos indivíduos no trabalho, na família e na sociedade são aparentemente neutras em termos de gênero, mas sabidamente são marcadas por um entendimento masculino desses mesmos papéis e que assim permanecem pelo poder que o domínio masculino tem nas relações mais cotidianas” (SOUZA, 2006, p. 202).

Mas o que tem sido pouco pontuado na análise das situações do "teto de vidro" dentro das organizações é a estrutura de poder produzida por meio de processos e práticas culturais elaboradas pela lógica masculina e internalizada e reproduzida pelas próprias mulheres 
(BOURDIEU, 2010). A dominação masculina encontra, assim, as condições de seu pleno exercício. As próprias mulheres aplicam, aceitam e justificam todas as condições que fazem com que a realidade pareça normal, principalmente nas relações de poder em que se veem envolvidas em esquemas de pensamento, que são produto da incorporação dessas relações de poder e que são fundamentadas nesta "ordem simbólica".

Em relação ao "teto de vidro" existente especificamente na educação superior, Tabak (2003) explana que nos cargos hierárquicos mais elevados das instituições de ensino superior e dos centros de pesquisa, predominam, de maneira absoluta, os homens - as mulheres se concentram nas posições inferiores; são poucas aquelas que conseguem chegar ao topo. Segundo o autor, isso acontece mesmo com a grande quantidade de mulheres que têm tido suas dissertações e teses aprovadas em seus estudos de pós-graduação.

Sendo assim, o fenômeno mencionado acontece de formas variadas na sociedade, dependendo da cultura. Para transpor esse limite, as mulheres precisam se adaptar às mais diversas exigências organizacionais e ao ambiente empresarial, que pode ser mais ou menos favorável ao seu desempenho, fazendo com que elas criem uma nova identidade profissional e desenvolvam com mais critério e consciência o seu processo de empoderamento (MELO, 2009).

\section{CONTEXTUALIZAÇÃO DA PESQUISA}

Para compreender o universo do ensino superior privado brasileiro é preciso voltar algum tempo, mais especificamente à década de 1990, quando Fernando Henrique Cardoso (1995 - 2002) implantou as Leis de Diretrizes e Bases da Educação Nacional (LDB/1996), que permitiram que a iniciativa privada abarcasse o ensino superior a fim de acelerar o crescimento do setor nessa área (FLEURY, 2013). Esse crescimento foi ainda mais acelerado no período de 2003 a 2010 do governo do presidente Luiz Inácio Lula da Silva, com a implantação de bolsas parciais ou integrais, como o Fies e o ProUni, desenhados para estudantes com baixa renda- ações sociais que permanecem no atual governo. O resultado foi uma elevação no número de alunos nas instituições, que culminaram em um aumento de mais de $70 \%$ de instituições de ensino superior privadas em uma década (BEMFICA, 2014). Sguissardi (2008) aponta que, neste contexto de expansão, quatro grupos educacionais brasileiros passaram a comercializar ações na Bolsa de Valores, como o grupo Anhanguera, Estácio de Sá, o Sistema Educacional Brasileiro e Kroton Educacional. Em seguida, em abril

REAd | Porto Alegre - Vol. 23 - No Especial - Dezembro 2017 - p. 126-157 
de 2013, houve uma fusão entre dois grandes grupos: a Kroton Educacional e a Anhanguera Educacional. Em setembro de 2013 o grupo Estácio de Sá comprou a Uniseb. Esses fatos mostram que o setor educacional vem se transformando em uma potência econômica (ALERIGI JÚNIOR, 2013). Nos últimos anos, outras fusões vêm sendo realizadas desenvolvendo um novo perfil econômico no campo educacional.

No último Censo da educação superior do Instituto Nacional de Estudos e Pesquisas Educacionais Anísio Teixeira (INEP) que faz a apresentação de dados por gênero, verificouse que, em 2012, 45,2\% dos docentes do ensino superior são do sexo feminino (INEP, 2012). No entanto, há uma discrepância entre o número de docentes mulheres em instituições de ensino superior e líderes gerais femininas nas mesmas. Barelli (2002) aponta alguns dados referentes a essa diferença, mostrando que enquanto nas salas de aula há um equilíbrio entre docentes de ambos os gêneros, nos cargos de alta hierarquia das instituições a diferença se mostra maior. Segundo a mesma autora, nas universidades federais, as mulheres representam $42 \%$ do corpo docente e menos de $10 \%$ entre os reitores.

Em Belo Horizonte, Minas Gerais, segundo dados do Ministério da Educação (INEP, 2012), há 86 Instituições de Educação Superior. Para esta pesquisa foi feito um estudo inicial, em uma amostragem de 52 instituições privadas com fins lucrativos e sem fins lucrativos da

cidade, que revelou que há apenas 20 mulheres no cargo de diretoria geral das instituições. É importante ressaltar também que foi levado em consideração, nesta pesquisa inicial, a maior hierarquia dentro de uma unidade de ensino, não sendo contabilizados presidentes gerais e outros cargos de grandes grupos educacionais que não lidam diretamente com a unidade institucional. A função de interesse desta pesquisa é a de maior gestor ou gestora das unidades de ensino superior localizadas em Belo Horizonte.

Portanto, assim como nas universidades publicas, nas instituições privadas a discrepância entre homens e mulheres em posições de comando é uma realidade. Para uma leitura mais assertiva sobre a trajetória das mulheres que chegaram ao cargo mais elevado de uma instituição de ensino particular, ou seja, que já estão avançadas em seu processo de empoderamento, foi proposta uma análise dos relatos sobre sua história de vida, conforme detalhada na metodologia.

\section{METODOLOGIA}

Primeiramente, realizou-se uma pesquisa no portal e-MEC, em 2015, para mapear as REAd | Porto Alegre - Vol. 23 - No Especial - Dezembro 2017 - p. 126-157 
instituições de ensino superior privadas da cidade de Belo Horizonte. Assim, foram levantadas 52 instituições de ensino superior considerando faculdades, centros universitários e universidades com fins lucrativos e sem fins lucrativos. Optou-se por pesquisar instituições de ensino superior privadas dada a especificidade do setor público, uma vez que os cargos docentes são preenchidos por concurso público, existe estabilidade funcional e, o acesso a cargos de alta gestão, está ligado a eleição, situando-se, assim, em outro contexto teórico.

Posteriormente, efetuou-se telefonemas a essas instituições para identificar o ocupante do cargo de mais alta hierarquia dentro de cada unidade de ensino selecionada e, consequentemente, identificar o gênero dos principais responsáveis destas instituições. No caso de instituições com mais de uma unidade, pesquisou-se se a diretoria era geral ou local; caso local, definiu-se quem era a pessoa responsável por cada uma das unidades. Essa etapa foi de grande relevância para se ter uma ideia quanto ao número de gestores versus gestoras há em instituições de ensino superior privadas da cidade de Belo Horizonte. Neste contexto, identificou-se apenas 20 instituições com mulheres ocupando cargos da alta direção, a saber: Reitora, Vice-Reitora, Diretora e Líder.

Assim, esta pesquisa, de natureza qualitativa, baseou-se na análise dos relatos de história de vida de três diretoras de unidades de ensino privadas localizadas em Belo Horizonte, pertencentes a grandes grupos educacionais brasileiros, sendo definidas pelo critério de acessibilidade. A abordagem qualitativa foi pertinente neste estudo por lidar com uma realidade não mensurável, que compreende uma gama de significados, aspirações, motivações, crenças, atitudes e valores, e que engloba um mergulho em um espaço profundo das relações, dos processos e dos fenômenos (GODOY, 1995) em voga no estudo das relações de gênero. A abordagem qualitativa de um problema justifica-se por tentar compreender a natureza de um fenômeno social (CHIZZOTTI, 2000).

Já o relato de história de vida é uma das modalidades de estudo em abordagem qualitativa (SPÍNDOLA; SANTOS, 2003). Nesses relatos, o que interessa ao pesquisador é o ponto de vista do sujeito de pesquisa; o objetivo desse tipo de estudo é compreender a vida nas condições em que ela é relatada e interpretada pelo sujeito (GLAT, 1989). Esses relatos permitem compreender as experiências biográficas em sua relação com a sociedade, a cultura e as instituições criadoras de significados de modo mais amplo (DENZIN, 1989). De acordo com Vergara (1998), os sujeitos de pesquisa são os que geram as informações necessárias para que a pesquisa aconteça. Ressalta-se que o número de casos para um estudo utilizando histórias de vida pode variar, a literatura apresenta desde estudos que se baseiam em apenas

REAd | Porto Alegre - Vol. 23 - No Especial - Dezembro 2017 - p. 126-157 
uma história de vida podendo chegar até 800 casos (NÓVOA, 1995).

A coleta de dados foi realizada no período de agosto a setembro de 2015 , com as diretoras que foram convidadas a falar sobre sua trajetória de vida profissional. Em seguida, foi solicitado a elas que aprofundassem seu discurso em determinadas áreas que tivessem relação com o objeto de estudo em questão. Essas informações foram gravadas, transcritas e, sucintamente expostas em uma seção especial deste artigo.

A história de vida das pesquisadas foi analisada por meio da técnica de análise de conteúdo, que, segundo Moraes (1999), conduz descrições sistemáticas, qualitativas, que ajudam no processo de interpretação de mensagens, na tentativa de compreender seus significados. Segundo o mesmo autor, a técnica pode ser usada para descrever e interpretar o conteúdo de toda classe de documentos e textos. Bardin (1979) define a análise de conteúdo como um grupo de técnicas para análise de comunicações visando a obtenção de descrição do conteúdo de mensagens e indicadores que permitam a inferência de conhecimentos referentes à produção ou recepção destas mensagens.

Para a análise dos relatos, considerou-se quatro variáveis relacionadas aos objetivos específicos desta pesquisa: visão das diretoras acerca de seu próprio empoderamento; vivência de situações de preconceito e dificuldades em sua trajetória que identificassem a dominação masculina; suas perspectivas de ascensão dentro das instituições onde atuam; e, por fim, nas atitudes e habilidades adquiridas em sua trajetória rumo à gestão educacional. Com o objetivo de documentar os relatos neste artigo, mas mantendo a privacidade das relatoras, estas receberam os nomes fictícios de Carmem, Júlia e Andreza.

\section{RELATOS DE HISTÓRIAS DE VIDA}

Este artigo contou com os relatos da história de vida profissional de três diretoras, que receberam os nomes fictícios de Carmen, Júlia e Andreza. As três gestoras pertencem a grandes grupos educacionais brasileiros e são as principais responsáveis pela gestão estratégica para a geração de resultados em suas unidades de ensino. É importante salientar que, diferentemente de instituições federais, em que o reitorado é definido por processos políticos para a escolha do reitor ou reitora, nas instituições privadas esse processo acontece por meritocracia, na medida em que há o interesse no cargo.

\subsection{RELATOS DE CARMEM}

REAd | Porto Alegre - Vol. 23 - No Especial - Dezembro 2017 - p. 126-157 
Carmem tem 49 anos, encontra-se em união estável e tem uma filha adolescente. Ela exerce o cargo de diretoria de unidade institucional há 8 anos, embora já faça parte da intituição há 15. Ela iniciou na instituição em que trabalha atualmente no setor de orientação educacional e profissional.Como parte de sua trajetória rumo à gestão educacional, Carmem graduou-se em Psicologia, cursou MBA em Gestão de Instituições Educacionais, além de ter se dedicado a duas pós-graduações na área de gestão de pessoas. Sua experiência profissional antes da de diretoria de unidade contou com uma vasta experiência em Recursos Humanos que lhe rendeu grande conhecimento, tendo sido iniciada aos 18 anos, perpassando por estágios em diversas áreas. Carmem trabalhou ainda na área de saúde mental, como monitora de psicopatologia; em penitenciárias, com ressocialização; e, depois de formada, continou trabalhando com Recursos Humanos, se dedicando a consultorias e trabalhos em hospitais.

Carmem define seu cargo como "repleto de responsabilidades para com pessoas e resultados institucionais", que, em sua visão, precisa ser exercido com muita ética e transparência. A diretora não gosta de utilizar a palavra "poder" em seu cotidiano, mas acredita que essa ideia de poder possa estar associada à tomada de decisões que cabe à diretoria e que ela preza para que seja realizada com muita prudência, mesmo em meio a um mercado altamente competitivo, conforme define.

Carmem relata acreditar que existiu, em sua trajetória, e ainda existem dificuldades que são impostas pelo fato de ser mulher em um cargo de diretoria. Ela compartilha a ideia de que, culturalmente, as mulheres não são formadas para ter e exercer o poder; um exemplo dado por ela é que a liderança muitas vezes não é formada na criação da mulher. No entanto, Carmem admite que muitas mulheres conseguem adotar, ao longo da vida, uma postura diferente. Em seu caso, ela assume ter tido uma educação na qual tinha a liberdade de escolha, o que impactou em sua vida profissional. Ela conta que ao adentrar o mercado de trabalho percebeu que os homens estavam em vantagem numérica em cargos de liderança e que eles tinham mais facilidade de crescer em uma empresa, de ter salários melhores; então, ela se viu com a necessidade de lutar de igual para igual e não se acomodar, nem de colocar obstáculos a si mesma. Ela mostra uma estranheza quanto ao fato de haver tantas mulheres no setor educacional, porém, ao começar a participar de reuniões de líderes desse setor, deparou-se com uma maioria absoluta masculina.

Carmem afirma que muitas vezes a própria mulher não acredita em si mesma, mas como ela havia tido líderes "inspiradores", conforme define, tanto masculinos quanto femininos, não foi contagiada por esse preconceito. Segundo seus relatos, o fato de ter tido 
líderes que acreditaram em seu trabalho, fez com que ela acreditasse que podia. No entanto, seu grande desafio profissional foi definido por conseguir manter uma relação com seu companheiro, ter filhos e continuar sendo valorizada pelo trabalho. Ela acredita ter conseguido concliar essas áreas por poder contar com ajuda na criação da filha.

A diretora diz que a sensibilidade ajuda a ter maior percepção quanto às diferenças e atuar melhor no ramo educacional. No entanto, ela define que a sensibilidade está na pessoa e não no gênero, uma vez que ela se depara, nesse meio, com homens que possuem grande sensibilidade e mulheres com pouca.

A característica crucial que Carmem define ter desenvolvido para atuar no mercado competitivo do ensino superior atual foi a resiliência; como estratégia de trabalho, ela diz não abrir mão de sua presença constante na instituição, nem da aproximação de seus funcionários, tanto administrativos quanto docentes.

Apesar de Carmem admitir não ter ambição, não consegue definir se a falta dela é uma característica própria ou se foi fruto de sua criação como mulher, educada para não querer ou precisar de tanto poder ou prestígio. Ela assume ainda que, às vezes, é a própria mulher que deixa de tentar e de se impor pela cultura e pela dominação masculina na qual está inserida e com a qual já se habituou. Embora ela não acredite que haja impedimentos contra a sua chegada a um alto posto de comando institucional, caso ela queira, ela chama a atenção para o fato de em seu grupo educacional haver mais homens nas posições mais altas da hierarquia.

\subsection{RELATOS DE ANDREZA}

Andreza tem 34 anos, é casada, sem filhos e atua no cargo de diretora de unidade em um grande grupo educacional há quatro anos, embora tenha iniciado seu trabalho na instituição como estagiária no setor de controladoria há quase dez anos. A diretora é graduada em Ciências Contábeis, pós-graduada em Controladoria Corporativa e já atuou em diversas áreas, incluindo projetos educacionais, serviços operacionais, financeiros e administrativos. Ela é certificada em Gestão de Negócios, consultora de planos de negócios, finanças corporativas, controle orçamentário, análise de viabilidade e gestão de pessoas.

Aos 18 anos, Andreza já tinha um cargo de confiança de gerente geral em uma grande empresa de telefonia, onde liderava um grande grupo de pessoas (apenas homens). Mas, pela vontade de ingressar na área de contabilidade, sua formação acadêmica, abriu mão da gerência na empresa de telefonia por uma vaga de estágio na instituição onde hoje atua como

REAd | Porto Alegre - Vol. 23 - No Especial - Dezembro 2017 - p. 126-157 
diretora. Dentro da instituição ela passou por todos os setores de controladoria, até chegar ao setor de orçamento e contabilidade, de onde, segundo seus relatos, é possível ter uma visão sistêmica de todo o processo da instituição, além de matrizes e centros de custo de negócios. Após essa vivência, recebeu a oportunidade de atuar nos centros de negócios, conforme conceitua, também conhecidos como unidades de ensino. Antes de gerir a atual unidade, trabalhou cuidando, ao mesmo tempo, de duas unidades com mais de 2.000 alunos cada uma.

Andreza pontua que seu cargo, com todos os desafios, reconhecimentos, bem como as oportunidades que sempre recebe da instituição, fazem com que ela experimente uma forte sensação de empoderamento, que a realizam enquanto profissional. A diretora conta ainda já ter recebido um prêmio de reconhecimento social de mulher destaque. Ela afirma não se lembrar de ter sentido dificuldades de relacionamento ou de realizar seus trabalhos por ser mulher, porém admite ter presenciado situações de preconceito contra conhecidas em outras organizações, mas não na instituição educacional. Ela se sente feliz em dizer que não teve apadrinhamento para estar em sua posição atual e explica que tudo ocorreu de forma "gradativa e natural". Afirma ainda que nunca teve dificuldade alguma de alcançar todos os objetivos organizacionais. Ela conta que o número de diretoras em seu grupo educacional vem crescendo e aponta que existe uma vice-diretora, no grupo dos cinco vice-diretores do grupo; relata também que o cargo de superintendente, posição acima da sua, também é ocupado por uma mulher. No entanto, ela afirma perceber em reuniões gerais, por exemplo, a tentativa de o homem se impor perante o grupo, o que ela classifica como uma tentativa de dominação.

Andreza admite ter tido apenas líderes homens, nos quais buscou inspiração para sua forma de gestão. Ela diz que aprendeu a ter firmeza na profissão por meio do exemplo desses homens, mas que não deixa de colocar sua característica pessoal na gestão, que é marcada pelo "jogo de cintura” para lidar com situações adversas.

Andreza acredita que a característica que tenha desenvolvido mais e melhor tenha sido a firmeza nas atitudes. Seus maiores desafios têm sido aliar a dedicação extrema ao trabalho, que chega a 18 horas por dia, à convivência familiar e eventos sociais. Afinal, conforme ela explica, "ainda há as viagens, que demandam dedicação de quase 24 horas". No entanto, ela se sente feliz por tantas conquistas profissionais, enquanto ainda é jovem, e por já ter conseguido mostrar a qualidade de seu trabalho, obtendo estabilidade financeira e ainda ter tempo de reconquistar o "tempo perdido", bem como pensar em planos pessoais para o futuro.

Andreza acredita que existem características predominantemente femininas, como “jogo de cintura", flexibilidade e sensibilidade, enquanto as masculinas envolvem uma maior

REAd | Porto Alegre - Vol. 23 - No Especial - Dezembro 2017 - p. 126-157 
objetividade. Ela acredita que as mulheres conseguem seus objetivos de formas mais sutis que os homens, e ela, embora aposte na objetividade e firmeza nas decisões, diz usar a flexibilidade e a comunicação constante como parte de sua gestão.

Quanto ao futuro, Andreza admite ser uma mulher ambiciosa e diz que pretende galgar outros postos, admitindo já ter recebido propostas da instituição envolvendo mudança de estado e de cargo, mas que não acha que seja a hora de assumir, uma vez que está com um trabalho recém-iniciado em uma unidade. No entanto, ela não vê impedimentos para chegar a cargos mais altos na organização em que atua.

\subsection{RELATOS DE JÚLIA}

Júlia tem 34 anos, é casada, tem duas filhas, de quatro e dois anos e um filho, de seis meses. Ela exerce o cargo de diretora institucional há apenas dois meses, mas está na instituição há seis anos e meio, tendo atuado previamente como docente e coordenadora de curso. A diretora possui curso técnico em eletrônica, graduação em engenharia eletrônica e telecomunicação e mestrado em engenharia elétrica.

Para que pudesse exercer a atividade de diretoria, Júlia conta que vem participado de um grupo há mais de um ano, para entender melhor como se relacionar com as pessoas.Sua experiência profissional iniciou-se aos 17 anos, após seu curso técnico, quando ela adentrou uma empresa multinacional onde atuou por 8 anos, ocupando desde o cargo técnico até o cargo de engenheira da produção, engenheira de testes e gestora da qualidade. Após 8 anos na empresa, decidiu procurar outros desafios e conseguiu uma posição em uma empresa na área de desenvolvimento de eletrônicos. Ela trabalhou com desenvolvimento de hardware por dois anos, e, após 10 anos no mercado, trabalhando diretamente com o processo produtivo e desenvolvimento de produtos, começou a procurar por programas de mestrado. Para se dedicar, pediu o desligamento da empresa e, nesse momento, foi convidada para ministrar aulas na instituição onde hoje atua como diretora, o que ela afirma ter sido uma "grande e agradável surpresa". Concomitantemente ao trabalho de docente, Júlia fazia vendas de software de gestão da produção como pessoa jurídica, trabalho que perdurou por três anos, até a primeira filha completar um ano. Nesse momento, por perceber a dificuldade de manter duas áreas de atuação, Júlia optou por atuar somente na área acadêmica. Trabalhou, então, como coordenadora de curso e professora por 3 anos. Ao engravidar da segunda filha, foi convidada para atuar no cargo de coordenadora de área, relacionando-se diretamente com os

REAd | Porto Alegre - Vol. 23 - No Especial - Dezembro 2017 - p. 126-157 
coordenadores de curso, o que ela julgou ter sido interessante. Nesse setor, ela ficou durante 2 anos, até engravidar do terceiro filho. Quando estava prestes a retornar da licença maternidade surgiu a oportunidade para direção de um campus. Ela tentou o processo seletivo durante a licença maternidade e retornou ao trabalho diretamente na posição de diretoria de unidade.

Júlia define-se como uma mulher empoderada em seu ramo de atuação e salienta que o poder em uma instituição está diretamente associado à pessoa ter a oportunidade de tomar decisões com a equipe, visando o sucesso estratégico para a empresa.

A diretora acredita ter vivenciado situações de preconceito enquanto exercia o cargo de engenheira e técnica, em seus empregos anteriores. Afirma inclusive ter recebido salários mais baixos pelo simples fato de ser mulher; mas não se recordou, durante o encontro, desse tipo de vivência enquanto gestora educacional, embora ela tenha citado que há, no ar, uma impressão de que a dominação masculina exista, de fato, e de que o "mundo é machista". Ela afirma também que sua maior dificuldade foi de caráter interno, consigo mesma, incluindo a dificuldade de relacionamento com pessoas, por se considerar demasiadamente objetiva, mas afirma que nenhum desses problemas se deu por problemas referentes a gênero. Além disso, ela divide sua trajetória em dois momentos: antes e após as crianças. Portanto, um outro desafio é manter a tranquilidade nos dois ambientes

Júlia afirma ter lidado tanto com homens quanto com mulheres líderes em sua trajetória profissional, então, talvez por isso, jamais tenha tido problemas em visualizar a mulher como líder em potencial. Ela acredita ainda que ser mulher não propicia vantagens nem desvantagens no setor educacional. Segundo seu ponto de vista, os comportamentos estão mais associados à sua personalidade e à forma como se enxerga e trata as pessoas ao seu redor.

Quanto ao futuro, Júlia afirma que tem a vontade de alcançar um posto acima do que ocupa e não vê, no grupo educacional em que atua, um impedimento pelo fato de ser mulher. Ela menciona ainda que há muitas mulheres em postos de comando acima de seu cargo, mas não menciona a quem pertencem os cargos mais altos da organização.

\section{ANÁLISE DOS DADOS DA PESQUISA}

A análise dos relatos foi sistematizada em quatro tópicos. O primeiro sobre a forma

como as diretoras enxergam o seu empoderamento. $\mathrm{O}$ segundo apontou a existência de

REAd | Porto Alegre - Vol. 23 - No Especial - Dezembro 2017 - p. 126-157 
situações de dificuldades, preconceitos e desafios pessoais e profisionais vivenciados em suas trajetórias. O terceito tópico analisou a visão dos sujeitos de pesquisa quanto às suas perspectivas de futuro dentro das instituições onde atuam, e, por fim, foram analisadas as atitudes e habilidades adquiridas, para a estabilidade no cargo.

\subsection{O EMPODERAMENTO NA VISÃO DAS DIRETORAS DE IES PRIVADAS}

A posição de diretor ou diretora dentro de uma instituição de ensino superior privado é considerada a de maior poder dentro daquela unidade específica. Dessa forma, é certo que as diretoras entrevistadas para este estudo precisam tomar muitas decisões ao longo dos dias, além de lidarem cotidianamente com um grande número de funcionários, alunos e comunidade. No entanto, com as recentes fusões e aquisições de faculdades pelo país, grupos gigantes no ramo da educação foram criados. Nesse novo contexto educacional, não se pode dizer que as diretoras à frente das unidades de negócio sejam totalmente empoderadas no seu ramo de atuação, por terem que prestar contas a profissionais de maior hirarquia dentro do grupo; contudo, já estão avançadas em seu processo de empoderamento profissional. Embora elas se sintam mulheres empoderadas de uma forma geral, demonstram diferentes noções do poder, conforme relatam:

(....) O quê que é poder? Ter mais responsabilidades? Eu me considero uma pessoa com muitas responsabilidades e eu tenho que exercer as atividades de uma forma muito ética.. Isso é ter poder? Eu tenho o poder de decisão em uma instituição, mas as decisões não podem passar só pela sua posição de comando. (Carmem)

Eu me considero[empoderada]. E o que me deixa muito feliz é que eu sempre fui reconhecida por isso; já vou completar 10 anos de [instituição] e sempre estou recebendo grandes oportunidades $e$ reconhecimento nesse trabalho (...) então, eu tenho essa sensação. (Andreza)

Assim, embora as diretoras vejam a manifestação do poder em seu trabalho de diferentes ângulos, todas elas se enquadram nos quesitos necessários para o empoderamento, segundo a ótica dos diversos autores mencionados no marco teórico deste estudo. Ao analisar, por exemplo, o conceito de empoderamento de Rawat (2014), que engloba o sentido de autorizar, delegar ou dar poder a alguém, é possível perceber, por meio das palavras das diretoras, que elas se sentem empoderadas em seu ramo de atuação por terem a oportunidade 
de tomada de decisões importantes como parte de suas rotinas.

Somados ao poder de decisão, percebe-se que as diretoras estão incluídas em relação à sua família, comunidade e sociedade, o que também mostra traços do empoderamento, na visão de Jejeebhoy (2000), que engloba a participação social e familiar, conforme verifica-se pelo relato de Andreza:

Hoje eu priorizo a minha vida pessoal. A minha agenda é muito mais voltada para questões familiares, para questões pessoais, e planejamento do que eu quero pra mim daqui pra frente, porque o profissional eu já consegui (...) Já até recebi um prêmio como mulher de destaque (...).

Segundo o modelo de Melo (2009), o empoderamento feminino perpassa pelos fatores cognitivo, subjetivo, político, econômico, social e cultural. A fala das diretoras confirmam seu empoderamento em todos esses quesitos, por meio de seus estudos contínuos (fator cognitivo); seus altos salários (fator econômico); sua liberdade para tomada de decisões dentro da instituição, o que indica a vivência constante de relações de poder (fator político); e o respeito que recebem de seus subordinados, da comunidade e da família (fator social). Contudo, quanto aos fatores subjetivo e cultural, algumas diretoras se mostraram desconfortadas e conscientes acerca da existência de uma certa dominação masculina em seu meio, conforme pode-se verificar no recorte do relato de Carmem: “Culturalmente, nós mulheres não somos formadas para ter poder. Isso não é formado na sua criação. No mercado de trabalho a gente sempre percebe que homens têm mais facilidade de crescer em uma empresa, de ter salários melhores e aí a gente precisa lutar de igual para igual. E escolhi lutar... “

Carmem, em outro momento, quando levada a se posicionar sobre a existência de um possível "teto de vidro" dentro das instituições educacionais, esclarece seu ponto de vista, que confirma seu desconforto em relação à cultura paternalista ainda dominante: " $E$ a dominação masculina, né?(...) de repente, as mulheres deixam isso acontecer pela dominância, pela cultura machista em que a gente sempre foi inserida. Desmistificar isso eu acho que leva um tempo" (Carmem).

Assim, quanto ao quesito empoderamento, é possível perceber que, embora as profissionais analisadas tenham grandes realizações em seu ofício, levando-as ao desfrute do poder dentro da instituição, percebe-se que sua autoconfiança esbarra na cultura paternalista ainda vivenciada nos dias atuais.

REAd | Porto Alegre - Vol. 23 - No Especial - Dezembro 2017 - p. 126-157 


\subsection{TRAJETÓRIA DE DIFICULDADES E PRECONCEITOS: INDÍCIOS DE DOMINAÇÃO MASCULINA NO RAMO EDUCACIONAL}

Para que fosse possível tratar desse tópico, as diretoras foram levadas a resgatar lembranças de sua trajetória enquanto gestoras, que indicassem a presença de algum tipo de dominação masculina, velada ou não, em seu meio de trabalho. Foi pontuado neste estudo que esse tipo de dominação pode acontecer de forma velada, por vezes imperceptível. Bourdieu (2010) reconheceu essa violência que se baseia apenas em questões concernentes ao status dado a uma pessoa unicamente por causa de seu sexo, como dominação simbólica. Muitas pessoas, inclusive as próprias mulheres, já se habituaram a ela e se encontram em um estado tamanho de dormência que acabam replicando ideias paternalistas e discriminatórias contra si próprias sem se darem conta disso. Essa dominação velada apenas pode ser percebida por meio de uma análise profunda das ações de um sujeito sobre o outro, afinal, segundo Foucault (1982), o poder não se tem, mas se exerce. E o exercício do poder pode se dar das mais variadas formas; no entanto, é perceptível nas relações humanas, uma vez que a sociedade já está acostumada a conviver com esse tipo de dominação.

Os relatos das diretoras demonstram a existência de uma dominação velada. Provavelmente, por estarem em uma posição de comando, elas não sofram o preconceito abertamente, mas ainda assim, o preconceito velado contra a mulher nessa posição acontece de formas variadas, conforme confirma-se abaixo:

Não me lembro de ter vivenciado alguma experiência, mas em todos os meus trabalhos eu sempre percebia que a maioria dos chefes são do sexo masculino e isso me irritava, porque por mais que a gente fosse bom profissional,você tem a maioria dos líderes masculinos, até no setor de educação. (...) quando você vai numa reunião de líderes do setor de educação, a maioria é homem. (Carmem)

De acordo com o relato acima, Carmem não se lembra de ter passado por uma situação em que houvesse uma discriminação aberta. No entanto, o seu relato demonstra a existência de um preconceito velado, que faz com que haja mais homens que mulheres em diversas posições de comando, salientando a existência de um possível "teto de vidro" no ramo educacional. Andreza, com menos tempo de atuação, afirma que nunca vivenciou isso na prática, mas afirma já ter presenciado tais situações com colegas.

Júlia, em especial, se dá conta de uma violência praticada contra a subjetividade da

REAd | Porto Alegre - Vol. 23 - No Especial - Dezembro 2017 - p. 126-157 
mulher, ao esperar que, exclusivamente em função de seu sexo, ela tenha determinado tipo de comportamento que vá ao encontro da expectativa do outro. Sobre isso, a diretora afirma que que em um relacionamento com as mulheres, percebe-se que as pessoas esperam maior delicadeza.

Assim, a expectativa geral que se tem da mulher ainda hoje é que ela esteja em uma posição de submissão em virtude da herança de anos de segregação feminina. Espera-se que ela cumpra bem seu papel de esposa, mãe e, se profissional, que saiba administrar bem todos os lados dessa relação que pode se tornar conflituosa. Esses conflitos, que envolvem a falta de engajamento da família em seus projetos, ou o fato de estarem constantemente trabalhando, dentro ou fora de casa, parecem ser os maiores fatores dificultadores para as diretoras.

Bom, os principais desafios, assim, pessoais, é você conseguir envolver a família no seu grande projeto de vida, que é relacionado à sua profissão (Andreza).

São 2 momentos diferentes: antes de ter as crianças e depois de ter as crianças. Antes de tê-las, [meu desafio] foi me preparar para o relacionamento, de saber liderar melhor (...) porque eu sou muito objetiva. Depois dos filhos, eu tenho que administrar a casa, a família, o marido, e o trabalho sem nenhum impacto nos dois lados (Júlia).

Andreza, em nenhum momento assume ter experimentado preconceito em seus quatro anos de experiência como diretora, nem em anos anteriores, enquanto foi gestora em outras empresas. Ela ainda salienta que as mulheres estão em posição inferior "não somente por preconceito, mas por [falta de] atitude". No entanto, suas próprias palavras mostram a existência de uma discriminação latente neste ramo, conforme pode-se verificar quando, ao mencionar um prêmio que recebera, ela diz que: "Ela não acreditou que realmente uma mulher fosse capaz de cuidar de duas instituições, de fazer consultorias, de trabalhar nas empresas. Então é por isso que eu falo (...) é possível que todo mundo tenha uma trajetória assim” (Andreza).

O relato de Andreza passa uma ideia contraditória com relação à sua visão acerca do empoderamento da mulher no ramo educacional. Deste modo, embora a última frase passe uma ideia positiva a respeito da possibilidade de ascensão da mulher, tomando por base a sua própria vida, dando a compreender que tal ascensão dependa exclusivamente dela, o início da fala mostra o quanto as pessoas se assustam quando percebem que uma mulher dirige duas unidades de uma grande instituição de ensino, o que reforça a ideia de que o esperado seria 
que um homem estivesse nesse posto de comando. Essa dualidade reforça a ideia de Bourdieu (2010), quando ele afirma que existe uma forma de poder que se exerce sobre os corpos, diretamente e como que por magia, sem qualquer coação física. Assim, as desigualdades de gênero existem e acontecem de forma velada, de forma obscura naquilo que é feito ou dito. Assim, embora nem todas as diretoras tenham assumido perceber a existência de discriminação em sua trajetória, foi possível encontrar indícios de dominação masculina em seus relatos, o que contribui para a confirmação da existência do "teto de vidro" para que se chegue ao cargo de gestão em instituições de ensino superior.

\subsection{PERSPECTIVAS DAS DIRETORAS QUANTO À ASCENSÃO PROFISSIONAL}

Embora a diretoria seja um cargo importante, nem sempre será o cargo mais alto dentro de uma instituição de ensino. Por esse motivo, este estudo buscou também averiguar, entre as diretoras, qual a sua percepção sobre a possibilidade de ingressarem em alguma posição acima da sua. Todas as diretoras afirmaram ser possível ocupar tais cargos, apontando que alguns de seus superiores, como superintendentes e vice-presidentes, são mulheres. Porém, seus próprios relatos indicam que essa presença feminina em grandes cargos é muito pequena, se comparada à quantidade de mulheres que ocupam as cadeiras de professoras nas instituições de ensino. A ideia que se tem é a de que as diretoras enxergam um lado positivo, afirmando que existem mulheres em altos cargos. No entanto, elas parecem não notar que essa presença é ínfima, conforme verifica-se no relato abaixo: "Dentro da [instituição] atual em que trabalho não vejo nenhum impedimento, até mesmo porque nós temos uma Vice Presidente. Nosso grupo de Vice Presidentes não é um grupo muito extenso, ele é formado por cinco [pessoas], e desses cinco, há uma representante feminina [...] (Andreza).

Carmem, ao ser questionada sobre a existência de algum impedimento ao tentar conseguir um cargo superior, reconhece a existência da dificuldade de se chegar a cargos mais elevados quando pontua que: "Não vejo exatamente problema... mas, assim... minha chefe direta é uma mulher, mas acima dela é um homem. Vai afunilando...”.

Quanto às diretoras obterem vantagem pelo fato de serem mulheres em um alto cargo de comando, as diretoras apresentaram opiniões divergentes. Enquanto Carmem e Júlia acreditam que as características são inerentes à pessoa e não ao sexo, Andreza acredita que algumas características reconhecidas como femininas ajudam. Ela parece não perceber que tais características também podem ser encontradas em homens, conforme verifica-se por meio

REAd | Porto Alegre - Vol. 23 - No Especial - Dezembro 2017 - p. 126-157 
de seu relato: "[...] o homem, ele é muito mais objetivo em certos pontos. A mulher consegue obter os mesmos resultados de uma forma muito mais sutil, gentil, porque ela vai do jeitinho mineiro "comendo pelas beiradas". Então eu acho que isso é uma coisa do perfil feminino".

Assim, Andreza mostra o lado gentil, cuidador e submisso que se espera da mulher; no entanto, sabe-se que nem toda mulher possui as características descritas, em razão de sua subjetividade. É um pensamento comum na sociedade, afinal, "a divisão entre os sexos parece estar na ordem das coisas, como se diz por vezes para falar do que é normal, natural, a ponto de ser inevitável" (BOURDIEU, 2010, p.17). Outras diretoras, contudo, mencionaram as características que julgam importantes no cargo, mas não apontaram qual sexo cada característica representa. Suas respostas parecem respeitar mais a ideia de individualidade e subjetividade do sujeito.

\subsection{ATITUDES E HABILIDADES ADQUIRIDAS E ESTRATÉGIAS UTILIZADAS}

Todas as diretoras afirmaram ter desenvolvido características que as ajudam rotineiramente na tarefa de gestão das instituições sob sua responsabilidade. Uma delas, por exemplo, afirmou ter desenvolvido firmeza. Ela justifica essa característica pelo fato de ter tido quase que somente líderes homens e afirma se espelhar neles para gerenciar sua equipe. Em seu ponto de vista, foi com homens que ela aprendeu a ter tal característica. Em suas palavras:

[...] eu sempre liderei com diretores e trabalhei com diretores, sempre me espelhei muito neles, então eu acho que é essa questão de manter a firmeza num projeto [...]. A única líder feminina que tive era muito mãezona, então muitas vezes ela deixava passar em branco alguma coisa por querer ajudar. Eu acho que o intuito não é esse, acho que como líder você tem que ter uma coisa muito mais focada. Você está aqui pra realmente proteger todo o dinheiro, todo patrimônio e todo o investimento dos acionistas da companhia (Andreza).

Esse recorte ilustra a ideia de Walby (1990), quando ele apresenta que o patriarcado é um sistema social no qual a figura masculina tem a autoridade central não somente na organização social, mas também no que tange a mulheres, crianças e propriedade. Assim, a gestora busca desenvolver as características que aprendeu com seus gestores homens, uma vez que isso é o que ela enxerga por natural e correto.

Júlia e Carmem afirmaram ter aprendido resiliência e a se relacionarem melhor. Júlia

REAd | Porto Alegre - Vol. 23 - No Especial - Dezembro 2017 - p. 126-157 
afirma fazer parte de um grupo de apoio para aprender a conviver melhor com as pessoas, por ter uma personalidade muito direta e objetiva, o que ela não considera ser tão interessante para uma gestora de uma instituição de ensino. Esse pensamento se torna relevante uma vez que, enquanto algumas mulheres se policiam para serem mais firmes, outras já se policiam para serem mais cordiais. Ou seja, enquanto uma tenta adotar características tidas como masculinas para encaixar em seus padrões de liderança apresentados no decorrer de sua trajetória de vida, outra tenta se encaixar em padrões ditos mais femininos para que consiga ter melhor aceitação entre a equipe, que espera mais gentileza e cordialidade ao se lidar com uma mulher. Seja em um caso ou no outro, a subjetividade é roubada da mulher para que ela adquira competências que serão aceitas, classificando-as como mais fortes.

Assim, para concluir as análises aqui apresentadas, pode-se retomar o pensamento de Bourdieu (2010), citado nas páginas deste estudo, uma vez que suas ideias defendem o fato de a dominação masculina estar enraizada no inconsciente das pessoas de tal forma que elas não mais a percebem. Muito do que essas gestoras vivenciam em seu dia a dia está coberto pelo véu da dominação e do preconceito, mas essa violência é simbólica e se apresenta de forma sutil e velada, mascarada por ideias tradicionalistas e patriarcais que colocam a mulher em segundo plano simplesmente por causa de seu sexo, e não por suas competências. Assim, sem uma postura crítica, que perceba essa ordem injusta, violenta e dominadora, a situação que se apresenta hoje, dificilmente poderá ser contida.

\section{CONSIDERAÇÕES FINAIS}

Este estudo teve como objetivo principal a análise das relações de poder e gênero existentes na trajetória de mulheres que se encontram à frente da gestão educacional de grandes grupos privados de Instituições de Ensino Superior. A metodologia se baseou em relatos de histórias de vida. Para tanto, três diretoras de instituições de ensino superior privadas apresentaram suas histórias de vida profissional e, a partir de suas histórias, propôsse uma análise do conteúdo destas à luz da teoria utilizada no referencial teórico deste artigo.

A trajetória das diretoras selecionadas mostrou que, embora a literatura mostre que a profissão docente tenha sido uma das facilitadoras para o acesso das mulheres ao mercado de trabalho, quando ela se depara com a possibilidade de assumir uma posição mais voltada ao gerenciamento empresarial, o acesso passa a ser mais limitado. Isso ocorre porque a profissão de gestora educacional vai além do magistério, principalmente nos cargos da alta hierarquia 
das instituições educacionais, assumindo processos de decisão, estabelecimento de metas e outras áreas envolvendo autoridade e posicionamento de poder.

Assim, tanto a literatura consultada para a elaboração do referencial teórico deste estudo, quanto as análises feitas a partir dos relatos de história de vida aqui expostos, mostram que as mulheres têm se sobressaído nos mais diversos campos. As três diretoras aqui apresentadas são mulheres que avançaram em seu processo de empoderamento e que vêm adquirindo respeito social e profissional. No entanto, isso não significa que sua trajetória tenha sido fácil ou livre de impedimentos para que elas conseguissem estar à frente da organização onde atuam; nem tampouco quer dizer que será fácil ascender a cargos mais elevados, muito embora não pareça, a olhos nus, haver qualquer tipo de impedimento que as impeça de avançarem.

Neste sentido, mesmo que nem todas tenham conseguido pensar em exemplos de situações que ilustrem uma possível discriminação, seus relatos mostram a existência de um preconceito velado, permeado por situações em que a dominação masculina se manifesta, mas sem ser notada, seja por meio de sua presença em massa em posições de maior comando, ou pelos valores culturais embutidos no subconsciente de cada pessoa. Seja como for, não se pode negar a existência de uma barreira que impeça que haja tantas mulheres em posições de comando quanto nas cadeiras das salas de professores.

O "teto de vidro", ainda presente em todas as áreas profissionais em que se apresenta a gestão, mostra na educação uma face cruel, já que se trata de uma área historicamente facilitadora da entrada da mulher no mercado de trabalho. No entanto, mesmo havendo muitas mulheres nos cargos de docência, poucas estão em posições mais elevadas. O estudo mostrou, portanto, que existe um afunilamento à medida que os cargos se elevam, que pôde ser percebido pelas diretoras e citados em vários momentos do artigo.

Esse "teto de vidro", é construído por homens e mulheres que replicam a discriminação, por vezes sem perceberem, como salienta Bourdieu (2010) sobre a dominação simbólica masculina. Essa dominação se esconde por detrás de uma cortina cultural, repleta de valores e percepções distorcidos, que ditam os comportamentos sociais vistos como naturais ou normais e os disseminam, sem levarem em conta os desejos e as capacidades da mulher, que é dotada das mesmas faculdades mentais e intelectuais que o homem. Percebese, ainda, que as diretoras entrevistadas exemplificam o modelo de análise de empoderamento proposto por Melo e Lopes (2011), mas que a dimensão cultural ainda traz os traços e resquícios de um sistema que vai além do patriarcalismo, o da dominação masculina, pois ele 
é mais complexo e legitimado pelas instituições, pelos homens e pelas próprias mulheres.

Entre as limitações do estudo, destacam-se o fato da pesquisa ter sido realizada em um único contexto geográfico, a cidade de Belo Horizonte, e se restringir às mulheres em alta posição hierárquica em instituições privadas, podendo ser analisada e comparada a situação das mulheres em instituições públicas. Quanto ao número de mulheres pesquisadas, tal fato poderia ser considerado uma limitação, mas o método de história de vida expande-se para uma potencialidade de compreensão de uma prática e realidade social. Sugere-se que o tema seja retomado ainda no mesmo segmento com sujeitos masculinos e femininos para o aprofundamento desta instigante questão.

\section{REFERÊNCIAS}

ALERIGI JUNIOR, A. da. Educação. Cade pede análise aprofundada de união Kroton Anhanguera. Revista Exame.com 2013. Disponível em: 〈http://www.exame.com/educacao>. Acesso em 01 out. 2015.

AQUINO, E. M. L.; MENEZES , G. M. S.; MARINHO, L. F. B. Mulher, saúde e trabalho no Brasil: desafios para um novo agir. Caderno de Saúde Pública, v.11, nº.02, p.281-290., Jun 1995. Disponível em: 〈http://www.ensp.fiocruz.br/csp/pes.html〉. Acesso em 15 out. 2015. BARDIN, L. Análise de conteúdo. Lisboa: Edições 70, 1979.

BARELLI, S. Lugar de mulher não é na reitoria. Folha Sinapse, 17/12/2002. Disponível em: <http://www1.folha.uol.com.br/folha/sinapse/ult1063u239.shtml>. Acesso em: 01 jul. 2015 .

BAXTER, J.; WRIGTH, E. O. The glass ceiling hypothesis: a reply to critics. Gender \& Society, v. 14, n. 6, December, 2000.

BEAUVOIR, S. O segundo sexo. Tradução Sérgio Milliet. Rio de Janeiro: Nova Fronteira, 1980.

BEMFICA, F. Extraclasse. Participação das IES privadas cresceu 73\% em uma década. Abr. 2014. Disponível em http://www.extraclasse.org.br/exclusivoweb/2014/04/participacao-dasies-privadas-cresceu-73-em-uma-decada/. Acesso em 30 set. 2015.

BILLING Y. D.; ALVESSON, M. Gender, managers, and organizations. Berlin/New York: W. de Gruyter, 1994.

BOURDIEU, P. A dominação masculina. 9 ed. Rio de Janeiro. Bertrand Brasil, 2010.

BOURDIEU, P. Razões práticas: sobre a teoria da ação. Trad. Mariza Corrêa. Campinas:

REAd | Porto Alegre - Vol. 23 - No Especial - Dezembro 2017 - p. 126-157 
Papirus, 2011.

CARREIRA, D. AJAMIL, M.; MOREIRA, T. (Org.). A liderança feminina no século 21: mudando o mundo. São Paulo: Cortez, 2001.

CASTELLS, M. O poder da identidade. São Paulo: Paz e Terra, 1999.

INSTITUTO NACIONAL DE ESTUDOS E PESQUISAS EDUCACIONAIS ANÍSIO TEIXEIRA (INEP). Censo da educação superior 2012: resumo técnico. - Brasília INEP, 2012. Disponível em <http://download.inep.gov.br/download/superior/censo/2012/resumo _ tecnico_censo_educacao_superior_2012.pdf>. Acesso em 30 set. 2015

CHIZZOTTI, A. Pesquisa em ciências humanas e sociais. 4 ed. São Paulo: Cortez. 2000.

CUNHA, C. M. da. Introdução: discutindo conceitos básicos. SEED-MEC Salto para o futuro - Educação de jovens e adultos. Brasília, 1999.

DENZIN, N.K. Interpretive biography. Newbury Park: SAGE Publications, Inc., 1989. DURBIN, S. Women, power and the glass ceiling: current research perspectives. Work, employment and society: extended review. 2002. Disponível em: http://jmi.sagepub.com. Acesso em 06 set. 2015.

ETHOS. Instituto. Perfil Social, Racial e de Gênero das 500 Maiores Empresas do Brasil e Suas Ações Afirmativas - Pesquisa. 2010. Disponível em:

$<$ http://www3.ethos.org.br/cedoc/perfil-social-racial-e-de-genero-das-500-maiores-empresasdo-brasil-e-suas-acoes-afirmativas-pesquisa-2010/\#.VeytVdJViko>. Acesso em 06 set./2015 FOUCAULT, M. Subject and Power. In: DREYFUSS, H.; RABINOW P. Beyond structuralism and hermeneutics. Brighton, The Harvester Press. 1982. FOUCAULT, M. Uma Trajetória Filosófica para além do estruturalismo e da hermenêutica. Rio de Janeiro: Forense Universitária, 1995. p. 231-249.

FLEURY, A. R. D. O trabalho e a docência em uma instituição de ensino superior pública: o caso dos professores de odontologia da Universidade Federal de Goiás. 2013. $297 f$ GLAT, R. Somos iguais a vocês: depoimentos de mulheres com deficiência mental. Rio de Janeiro: Agir; 1989.

GODOY, A . S. Pesquisa qualitativa: tipos fundamentais. Revista de Administração de Empresas, São Paulo, v. 35, n. 3, p. 20-29, mai/jun, 1995.

GOMES, A. F. O outro no trabalho: mulher e gestão. Revista de Gestão- REGE, São Paulo, v. 12 , n. 3, p. 1-9, set. 2005.

HULTIN, M. Some take the glass escalator, some hit the glass ceiling? Career consequences of occupational sex segregation. Work and occupations, v. 30, n. 1, pp. 30-61.

REAd | Porto Alegre - Vol. 23 - No Especial - Dezembro 2017 - p. 126-157 
2003.

IBGE: Mulher no mercado de trabalho: perguntas e respostas. 2012 Disponível em: http://www.ibge.gov.br/home/estatistica/indicadores/trabalhoerendimento/pme_nova/Mulher Mercado_Trabalho_Perg_Resp_2012.pdf. Acesso em: 18/jul/2014

JEJEEBHOY, S. J. Women's autonomy in rural India: Its dimensions, determinants, and the influence of context. In: PRESSER, H.; SEN, G. (Eds.) Women's empowerment and demographic processes: moving beyond Cairo. New York: Oxford University Press. 2000. LEITE, C. L. de P. Mulheres: muito além do "teto de vidro". São Paulo: Atlas, 1994. LOURO, G. L. Mulheres na sala de aula. In: DEL PRIORI, M. (Org.) História das mulheres no Brasil. São Paulo: Contexto / UNESP, 1997.

LOURO, G. L. Pedagogias da Sexualidade. In: LOURO, G. L. O corpo Educado: pedagogias da sexualidade. 3 ed. Belo Horizonte: Autêntica Editora, 2010.

MELO, M. C. O. L (Coord). Empoderamento de Mulheres Gerentes: estudo de casos em empresas do setor bancário, industrial e informática. 2009. 116f. (Relatório de Pesquisa) Núcleo de Relações de Trabalho e Tecnologias de Gestão - NURTEG, Faculdade Novos Horizontes - Centro Nacional de Desenvolvimento Cientifico e Tecnologia - CNPQ, Belo Horizonte.

MELO, M. C. O. L.; LOPES, A. L. M. Empowerment de mulheres gerentes: construção de um modelo teórico para análise. In: XXXV ENCONTRO DA ANPAD. Anais... Rio de Janeiro set/2011.

MELO, M. C. O. L. Mulheres gerentes entre o empoderamento e o "teto de vidro". In: FREITAS, M. E. de; DANTAS, M. (Orgs.). Diversidade sexual e trabalho. São Paulo: Cengage Learning, 2012. p. 337-372.

MORAES, R. Análise de conteúdo. Revista Educação. Porto Alegre, v. 22, n. 37, p. 7-32, 1999.

MOTOWIDLO, S. J. Information processing in personnel decisions. In: ROWLAND, K. M.; FERRIS , G. R. (Eds.), Research in personnel and human resources management. v. 4. Greenwich, CT: JAI Press. 1986. p. 1-44.

NÓVOA, A. Os professores e as histórias da sua vida. In: NÓVOA, A. (Org.). Vidas de professores. 2. ed. Porto: Porto Editora, 1995. p. 11-30.

PERROT, Michelle. Minha história das mulheres. São Paulo, editora Contexto, 2007.. POWELL, G; BUTTERFIELD, A. Investigating the "Glass Ceiling" phenomenon: an empirical study of actual promotions to top management. The Academy of Management

REAd | Porto Alegre - Vol. 23 - No Especial - Dezembro 2017 - p. 126-157 
Journal, v. 37, n. 11, p. 68-86, 1994.

PROBST, E. R. A Evolução da mulher no mercado de trabalho. Instituto Catarinense de Pós-Graduação ICPG. Santa Catarina. 2003. Disponível em:

http://www.posuniasselvi.com.br/artigos/rev02-05.pdf. Acesso em: 25 Ju. 2015.

RAY, S. Understanding patriarchy. 2006. Disponível em:

http://www.academia.edu/4995045/Understanding_. Acesso em 13 Ago. 2015.

RAWAT, P. S. Patriarchal Beliefs, Women's Empowerment, and General Well-being. The Journal for Decision Makers, v. 39, n. 2, p. 43-55, 2014.

RIBEIRO, A. I. M. Mulheres educadas na colônia. In: LOPES, E. M. T.; FARIA, L. M. F.; VEIGA, C. G. ()rgs). 500 anos de educação no Brasil. Belo Horizonte: Autêntica, 2000. p.79-94.

SGUISSARDI, V. Modelo de expansão da educação superior no Brasil: Predomínio privado/mercantil e desafios para a regulação e a formação universitária. Educação \& Sociedade, v. 29/105, p. 991-1022, 2008.

SOUZA, A. Perfil da gestão escolar no Brasil. Tese de Doutorado (Educação). Pontíficia Universidade Católica de São Paulo. São Paulo: PUC -SP. 2006 SPINDOLA, T.; SANTOS, R. da S. Trabalhando com a história de vida: percalços de uma pesquisa(dora?). Rev. Esc. Enferm. USP, v. 37, n. 2, p.119-126, 2003.

STAMATTO, M. I. S. Um olhar na historia: a mulher na escola (Brasil: 1549 - 1910). II Congresso Brasileiro de História da Educação, Natal, 2002.

STAMATTO, M. I. S. Um olhar na História: a mulher na escola (Brasil:1549-1910). In: História e Memória da educação Brasileira, 2002, Natal. II CONGRESSO BRASILEIRO DE HISTÓRIA DA EDUCAÇÃO, 2002. Disponível em:

http://www.sbhe.org.br/novo/congressos/cbhe2/pdfs/Tema5/0539.pdf. Acesso em: 13 de set de 2015.

STEIL, V. Organizações, gênero e posições hierárquicas: compreendendo o fenômeno do “teto de vidro". Revista de Administração, São Paulo v. 32, n.3, p.62-69, julho/setembro 1997.

TABAK, F. Gênero, conhecimento, ciência e poder. In: CARVALHO, M. E. P. de ; PEREIRA, M. Z. C. (Orgs.). Gênero e Educação: múltiplas faces. João Pessoa: Editora Universitária - UFPB, 2003.

VERGARA, S. C. Projetos e Relatórios de Pesquisa em Administração. 2 ed. São Paulo: Atlas, 1998.

REAd | Porto Alegre - Vol. 23 - No Especial - Dezembro 2017 - p. 126-157 
WALBY, S. Theorizing patriarchy. Oxford, London: Basil. Blackwell. 1990

REAd | Porto Alegre - Vol. 23 - No Especial - Dezembro 2017 - p. 126-157 